NJE Vol. 36: 71-80, 2020

Nigerian Journal of Entomology

Published by the Entomological Soc. of Nig.

www.esnjournal.com.ng

DOI.10.36108/NJE/0202/63.01.80

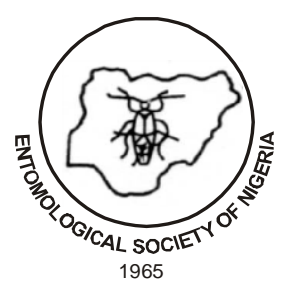

\title{
Insects and Their Products as a Potential Source of Food, Feed and Economic Security: A Review
}

\author{
Dattijo, S. A., ${ }^{1 *}$ Ajayi, F. A., ${ }^{2}$ Garba, M., ${ }^{1}$ Ahmad, M. $^{3}$ and Jinjiri, A. ${ }^{4}$ \\ ${ }^{I}$ Department of Pest Management Technology, Audu Bako College of Agriculture \\ Dambatta, Kano State \\ ${ }^{2}$ Department of Agronomy, Faculty of Agriculture, Shabu-Lafiya Campus, Nasarawa State University \\ Keffi, Nigeria \\ ${ }^{3}$ Department of General Studies, Audu Bako College of Agriculture, Dambatta, Kano State \\ ${ }^{4}$ Department of Biological Science, RMK CARS, Tudunwada, Kano State
}

\begin{abstract}
Due to many ways by which they are exploited, insects and their products could be a very big business. They are sold for agricultural protection, crop pollination, as well as human, livestock and pet nutrition. In addition, their products are sold for pharmaceuticals, health, and the implements for research, art works and a host of other uses. This review focused on commercialization of insects and their products with a view of sharing existing knowledge on global commerce of various insects and their products. Available literature revealed that there was an increase in demand for edible insects in the United States of America and prices were as high as $\$ 150 \mathrm{~kg}^{-1}$. Similarly, between 2010 and 2015, animal feed market in the United Kingdom grew at 3.5\% annually and is currently worth $£ 5$ billion. Because of its scarcity, high demand, and recognition of its healing properties, royal jelly, one of the most sought after from bee products commands astronomical price internationally. In addition, no any other industry could generate high level of employment as sericulture, especially in rural areas where it takes 11 workdays to produce a $\mathrm{Kg}$ of raw silk. The contribution insects and their products can give to improve the economy of a developing country such as Nigeria is considerable, but underestimated or neglected. Insects are unlikely to make a major contribution in the near future, but the idea that they are potential source of overcoming the economic problems is not as farfetched as it seemed. Therefore, there is the need to adopt an added value approach to insects and their products and sensitize as well as encourage small-scale farmers, who are disadvantaged in international market participation due to lack of access to information, services, technology or the capacity, to produce larger volumes of quality insect products.
\end{abstract}

Keywords: Insects, commercialization, economic security, food, feed, entrepreneur.

*Correspondence email:

abduljalaldattijo@yahoo.com 


\section{INTRODUCTION}

Gathering and/or farming insects could offer unique employment and income-earning opportunities in developing countries, particularly, but not exclusively, for the poor in urban and rural areas of West Africa). In many cases, insect collection and cultivation can serve as a livelihood diversification strategy that provides multiple incomegenerating opportunities for households. For example, silkworms, ants and bees can be considered as multipurpose production systems; silkworms can be used for food and fibre, and weaver ants, Oecophylla longinoda (Latreille) combat pests and can be used as food (Offenberg and Wiwatwitaya, 2009). In case of bees, both the honey and the larvae can be harvested as food (Murray et al., 2001).

Insects and their related products can be mass-produced and sold for crop protection (beneficial insects), crop pollination and health therapy, as well as for human, livestock and pet nutrition. They are also used for research, collectors' items and a host of other uses in international markets (Costanza, 1997). Many types of insects are sold live, however, insect products account for the majority of insect commercialization (Kampmeier and Irwin, 2003). Consequently, insect products are gaining more and more attention worldwide due to many ways by which they are exploited (Cerritos, 2011; Fontaneto et al., 2011; Mariod, 2011; Premalatha et al., 2011; Chae et al., 2012; FAO, 2012).

In developing countries however, insects gathered, from wild populations in nature, on farmlands or in forests, are mainly used for home consumption and local marketing. In addition to home consumption by the gatherer and his family, excess of the gathered insects and/or their products are sold for petty cash at local markets or in street food stalls by the gatherer or their family members. Occasionally though, excess may be sold directly to consumers or to middlemen and retailers at farm gate (HMI, 2012).

This review was conducted with the view of:

i. sharing existing knowledge on global farming, utilization and commerce of various insects and insect products,

ii. highlighting the role insects and insect products can play in job, livelihood and economic securities for individuals in particular and the nation in general

iii. raising awareness on the potentials of insects and insect products as good sources for national and international trade.

\section{General Perception on Insect Commercialization}

Capturing, processing, transporting and marketing of edible insects and their products provide important job, income and livelihood opportunities for undetermined number of people around the world. Traditionally, these activities were all locally based and largely under-recognized (Kampmeier and Irwin, 2003). Recently, however, more sophisticated and widereaching marketing and commercialization of edible forest insects and their products have been advanced, which include attractive packaging and advertisement (Kampmeier and Irwin, 2009).

Insects and their products regularly fetch high prices, higher than the crops from which they were collected and often higher than conventional fish and meat whether beef, chicken or pork (Munthali and Mughogho, 1992; Chidumayo and Mbata 2002). To that effect, Durst and Shono (2008) believed that creating a wider market for food insects and 
insect products could provide economic incentive for developing countries.

In developed countries, insect rearing and processing has great income-earning potential. For example, in USA live wasps are quite expensive, selling at around US\$150 per kilogram at harvest. Even then, demand is increasing to the extent that wasp foodstuffs are imported from other countries such as Republic of Korea, China and New Zealand. Similarly, the Asian giant hornet, Vespa mandarinia (Smith) is retailed at the same price, but is yet to be imported (Nonaka, 2008). In the same vein, consumers in the United Kingdom and Northern Ireland purchase (online) $70 \mathrm{~g}$ of weaver ant $(O$. longinoda) pupae for $€ 7.50$, while in the Netherlands, $50 \mathrm{~g}$ of yellow mealworm (Tenebrio molitor L.) and lesser mealworm (Alphitobius diaperinus (Panzer)) costs $€ 4.85$. Moreover, 35 migratory locusts (Locusta migratoria L.) cost (online) €9.99. Similarly, in Oaxaca, Mexico, chapulines (grasshoppers of the genus Sphenarium) are sold for $€ 12$ per $\mathrm{kg}$ (FAO, 2012) but just to mention a few.

\section{Human Bite Back (Insects for Food)}

There is growing concern about the ability to feed the ever increasing population.
Population trends suggest that there will be 9.6 billion people on the planet by 2050 (Gerland et al, 2014) with food demand growing by $60 \%$ (Alexandratos and Bruinsma, 2012). Insects are unlikely to make major contributions to the world's food supply in the near term, but the idea that insects might help overcome global hunger and malnutrition is not as farfetched as it seemed (Schabel, 2008). Apart from the advantage of sheer numbers, rapid reproduction rates and high fecundity, even with only a relatively few species being eaten by humans, the incredible numbers of insects in the world, estimated at $10^{-18}(10$ quintillion) individuals alive at any given time, can add up to massive quantities of potential food supply and market trade (Durst, and Shono, 2008).

Worldwide, 1,700 species of insects are reported to be used as human food. Table 1 identified them according to taxonomic orders, common/English names and number of species. Four insect orders predominate: Coleoptera, Hymenoptera, Orthoptera and Lepidoptera; accounting for 80 percent of the species eaten. Moreover, the Americas and Africa recorded the highest number of insect species eaten as food (Table 2) (RamosElorduy, 2005).

Table 1: Number of edible insect species reported in the world

\begin{tabular}{lll}
\hline Order & Common/English name & Number of species \\
\hline Thysanura & Silverfish & 1 \\
Anoplura & Lice & 3 \\
Ephemeroptera & Mayflies & 19 \\
Odonata & Dragonflies & 29 \\
Orthoptera & Grasshoppers, cockroaches, crickets & 267 \\
Isoptera & Termites & 61 \\
Hemiptera & True bugs & 102 \\
Homoptera & Cicadas, leafhoppers, mealybugs & 78 \\
Neuroptera & Dobson flies & 5 \\
Lepidoptera & Butterflies, moths (silkworms) & 253 \\
Trichoptera & Caddis flies & 10 \\
Diptera & Flies, mosquitoes & 34 \\
Coleoptera & Beetles & 468 \\
Hymenoptera & Ants, bees, wasps & 351 \\
\hline Total & & $\mathbf{1 , 6 8 1}$ \\
\hline Source: Ramos & & \\
\hline
\end{tabular}

Source: Ramos-Elorduy (2005). 
Table 2: Number of edible insects per continent

\begin{tabular}{llll}
\hline Continent & $\begin{array}{l}\text { Number of species } \\
\text { Recorded }\end{array}$ & Percent of total & $\begin{array}{l}\text { Number of } \\
\text { countries }\end{array}$ \\
\hline Asia & 349 & 20 & 29 \\
Australia & 152 & 9 & 14 \\
Africa & 524 & 30 & 36 \\
Americas & 679 & 39 & 23 \\
Europe & 41 & 2 & 11 \\
\hline Total & $1745^{*}$ & 100 & 113 \\
\hline
\end{tabular}

* The world total is actually 1681 ; some species occur in more than one continent, hence the higher total.

Source: Ramos-Elorduy (2005).

\section{Insects for Feed}

Beyond human food, insects provide highly nutritious food sources for domestic animals and livestock (Kampmeier and Irwin, 2003). Animal feed market is large and growing; global demand for livestock feed is estimated to be worth $£ 236$ billion (US \$370bn) (Global Food Security, 2015) and FAO (2013) estimated that commercial feed production will need to increase by $70 \%$ by 2050 to meet the growing demand of protein for the livestock sector. The Global Food Security (2015) reported that between 2010 and 2015 animal feed market in the United Kingdom alone grew $3.5 \%$ annually and is currently worth $£ 5$ billion

It is clear that a range of different approaches and sustainable protein sources will be needed to meet the growing demands of protein for animal feed, one of which must come from insects (FAO, 2012). Producers in China, South Africa, Spain and the United States are already rearing large quantities of flies for aquaculture and poultry feed (Global Food Security, 2015). There is thus, a significant opportunity for developing countries to fill the existing gap, especially in terms of competitiveness, reduced reliance on imports and potentially increase export of protein for animal feed (FAO, 2012).
The poultry industry has expanded rapidly in developing countries in the last two decades. Grasshoppers, crickets, cockroaches, termites, lice, stink bugs, cicadas, aphids, scale insects, psyllids, beetles, caterpillars, flies, fleas, bees, wasps and ants have all been used as complementary food sources for poultry (Ravindran and Blair, 1993). In addition, among the most promising species for industrial feed production are black soldier flies, common housefly larvae, silkworms and yellow mealworms, while grasshoppers and termites are also viable, but to a lesser extent (Alexandratos and Bruinsma, 2012).

\section{Creating an Entrepreneur from Insects and Insect Products}

Although, more emphasis was given on the use of insects as edible food and livestock feed, it should be noted that human use of insects and their products is wider (Tables 3, 4 and 5). Among fine fabrics made of natural products such as wool, cotton, linen, and leather, silk is usually the most highly prized (Cherry, 1987). It is estimated that sericulture can generate 11 workdays of employment per $\mathrm{Kg}$ of raw silk production. No any other industry could generate this level of employment, especially in rural 
areas; hence, sericulture is used as a tool for rural reconstruction. Sericulture also provides vibrancy to village economies, where $57 \%$ of the gross value of silk fabrics flows back to the rural cocoon growers (Umesh et al., 2009).

Beekeepers manage their hives, moving bees from field to field to ensure crop pollination. They buy high-quality queen bees from specialized suppliers. In a multibillion dollar industry, the commercial apiaries lease their beehives to crop producers. Each year, in the United States alone; nearly 100 different crop species are pollinated by the labour of these domesticated worker honey bees. $\$ 15$ billion worth of crops (fruits, vegetables, flowers) are pollinated by the domesticated honey bees annually (Beekeeping/ Apiculture/ Imkerei/ Apicultura, 2002). Other important products form the honey bee included bee honey, honey wax, honey comb, royal jelly, bee pollen, and propolis. Royal jelly, one of the most difficult of all insect products to harvest, commands astronomical prices because of its scarcity, high demand, and the recognition of its healing properties; is sold by many health food companies (Krell, 1996). These products are internationally sold as good sources food to deal with variety of ailments from anorexia to insomnia to cardiovascular diseases, and to promote wound healing (Kampmeier and Irwin, 2009).

The venom of honey bees is used to ameliorate inflammatory and autoimmune conditions such as multiple sclerosis, arthritis, rheumatism, chronic pain, neurological diseases, asthma, and dermatological conditions. The venom can be administered by humans or injected via the sting of a bee. Venom therapy is widely used in China, Korea, Bulgaria, Romania, Russia, Brazil, and the United States (Krell, 1996).

Table 3: Useful products produced from insect secretions and pigments

\begin{tabular}{|c|c|c|}
\hline Product & Application & Producer \\
\hline Silk & $\begin{array}{l}\text { Textiles, strings for leaders in, } \\
\text { fish lines, musical instruments } \\
\text { and wound sutures }\end{array}$ & $\begin{array}{l}\text { Bombycidae, Lasiocampidae } \\
\text { Saturniidae, Thaumetopoeidae }\end{array}$ \\
\hline Shellac, lac & Paint, varnish, ink, food dye & $\begin{array}{l}\text { Lacciferlacca } \text { Kerr } \\
\text { (Lacciferidae) }\end{array}$ \\
\hline Chitosang & Polymer for food packaging & chitin in the exoskeleton \\
\hline Cochineal & $\begin{array}{l}\text { Lacquer, paint, unguent, cosmetics, } \\
\text { coloring beverages }\end{array}$ & $\begin{array}{l}\text { Llaveia axin (Llave) } \\
\text { (Margarodidae) }\end{array}$ \\
\hline Tuna blood & $\begin{array}{l}\text { Dye for textiles and leather, } \\
\text { food colouring, cosmetics }\end{array}$ & $\begin{array}{l}\text { Dactylobius coccus Costa } \\
\text { (Coccidae) }\end{array}$ \\
\hline Oak red & Dye & Coccusilicis \\
\hline Armenian red & Dye for oriental rugs & Porphyrophora hamelii Brandt \\
\hline Polish red & Dye and food colourant & Margarodes polonicus \\
\hline Iron gall nut & Ink & Cynipidae \\
\hline
\end{tabular}

Source: Schabel (2008) 
Table 4: Useful products and by-products from honey bee

\begin{tabular}{|c|c|c|}
\hline Product & Application & Producer \\
\hline Honey & Food, beverages & Apidae \\
\hline Honeydew (manna) & Food, beverages & Homoptera, Formicidae, Apidae \\
\hline Beeswax & $\begin{array}{l}\text { Candles and more than } 100 \\
\text { other industrial uses }\end{array}$ & Apis (Apidae) \\
\hline Honey comb & $\begin{array}{l}\text { Candles, polish, paper } \\
\text { colouring, sizing }\end{array}$ & Apis (Apidae) \\
\hline
\end{tabular}

Source: Schabel (2008)

Table 5: Pharmaceutical/Therapeutic products from insects

\begin{tabular}{|c|c|c|}
\hline Pharmaceutical/Therapy & Treatment or function & Producer \\
\hline Honeydew and honey & $\begin{array}{l}\text { Antioxidants, skin and respiratory } \\
\text { problems }\end{array}$ & $\begin{array}{l}\text { Apidae, Homoptera in } \\
\text { combination with Formicidae or } \\
\text { Apidae }\end{array}$ \\
\hline Propolis ( bee glue) & $\begin{array}{l}\text { Antibiotic, anti-diabetic and anti- } \\
\text { ulcer, chewing gum, } \\
\text { automobile wax }\end{array}$ & Apidae \\
\hline Royal jelly & $\begin{array}{l}\text { Cholesterol-lowering, dietary, } \\
\text { anorexia, insomnia, cardiovascular } \\
\text { diseases, and to promote wound } \\
\text { healing }\end{array}$ & Apidae \\
\hline Chinese caterpillar fungus & Tonic, astringent & $\begin{array}{l}\text { Cordyceps sinensis infecting } \\
\text { infecting Hepialus armoricanus } \\
\text { Oberthuer (Hepialidae) }\end{array}$ \\
\hline White muscardine fungus & Stroke & $\begin{array}{l}\text { Beauveria bassiana infecting } \\
\text { Bombyx mori Certain Phasmidae } \\
\text { and Lepidoptera }\end{array}$ \\
\hline Frass & Antidiarrhoea & \\
\hline Antivenin & Wasp and bees stings & Vespidae, Apidae \\
\hline Bee venom & $\begin{array}{l}\text { Apitherapy: arthritis, multiple } \\
\text { sclerosis, rheumatism, chronic pain, } \\
\text { neurological diseases, asthma, and } \\
\text { dermatological conditions. }\end{array}$ & Apidae \\
\hline Chinese galls & Sores, cough, diarrhoea & $\begin{array}{l}\text { Malaphis chinensis (Bell) } \\
\text { Formicidae }\end{array}$ \\
\hline Ants & Hepatitis B, surgical incisions & \\
\hline Maggots & $\begin{array}{l}\text { cleanse wounds of necrotic tissue, } \\
\text { abscesses, burns, cellulitis, } \\
\text { gangrene, ulcers, osteomyelitis, and } \\
\text { mastoiditis. }\end{array}$ & $\begin{array}{l}\text { Phaenicia sericata } \\
\text { (Meigen)Diptera Calliphoridae }\end{array}$ \\
\hline Blister beetles & Vesicatory, warts, aphrodisiac & Meloidae \\
\hline
\end{tabular}

Source: Schabel (2008) 
According to Juma (1993), live ants particularly Amazonian army ants and carpenter ants of Africa, India, and the Mediterranean region are used to close surgical incisions. Similarly, the Genetics Society of America (1997) stated that with increase in resistance to antibiotics since late 1980 s, there has been a resurgence of interest in the maggot debridement therapy. Maggot of the green bottle fly, Phaenicia sericata (Meigen) is employed to cleanse wounds of necrotic tissue, while healthy underlying tissues are not attacked. Maggots have been used to treat abscesses, burns, cellulitis, gangrene, ulcers, osteomyelitis, and mastoiditis.

One of the best ways to counter the buildup and devastation caused by insect pests is to unleash their own natural enemies upon them. A vibrant industry is built on supplying the natural enemies or "beneficials" needed to manage pests and pest outbreaks, both for protecting agriculture and human health. According to Constanza (1997) insects as pests and human competitors can destroy or eat $\$ 5$ billion worth of domestic crops. Natural biological control provided mostly by insects is valued at over $\$ 400$ billion per year. On the other hand, not only living insects are marketed, dead insects and products derived from them can also be of high commercial value. In fact, insect products and by-products probably account for the greater share of insect commercialization (Tauber et al., 2000). A common dye (carmine) used to colour food and textile red is also from insects. Similarly, rubber-like protein called resilin that enables insects to jump has both industrial and biomedical applications (Elvin et al., 2005). Chitosan, a material derived from chitin in the exoskeleton, is a potential polymer for food packaging (FAO, 2013). Fats from insects are extracted for mechanical use (Makkar et al., 2014).
Other potentially miscellaneous enterprises form insects and their products include:

i. commercial butterfly industry, which is now vibrant in Thailand, Malaysia, Philippines, El-Salvador, Costa Rica, Taiwan, Kenya, Madagascar, and the United States. Exotic butterflies are released during ceremonies instead of rice, birdseed, and confetti.

ii. compact discs (CDs) are recorded and sold for households that wish to bring that calming quality of nature into the home. Among the insect sounds recorded and marketed are those of cicadas, grasshoppers, tree crickets, mole crickets, ground crickets, and katydids singing; June beetles flying; honey bees, bumblebees, yellow jackets.

iii. certain insects lend themselves or their products to the making of spectacular jewelry. Beetles are probably the most notable because of their durable, often iridescent, hardened forewings, called elytra, and interesting body shapes. They can be made into brooches or encased in plastic as key holders and paper weights (Akre et al., 1991).

\section{CONCLUSION}

In Nigeria, little or no attention has been given to useful insects, insect products and by-products; however, they have considerable economic potential. In Nigeria, there are many species and vast numbers of insects representing significant bio diverse resources that are still not fully utilized. There are enormous opportunities to establish (where there is none) and expand (where it exists) insect gathering and/or farming in Nigeria. This will certainly enhance food security, 
improve livelihood, create job opportunities and potentially generate extra income in international trade. The abundant edible insects, insect products and by-products in this country could be managed at different levels and capacities. However, the most difficult task may be in adding value to the potentially useful insects and insect products and making people to accept the business.

\section{RECOMMENDATIONS}

From the above write up, it is therefore suggested that:

i. indigenous knowledge of edible insects, insect products and byproducts should be promoted through extension services, workshops, seminars and conferences,

ii. trade and value chains should be established to develop marketing strategy that will be responsible for which industries to establish and what consumers to target;

iii. small, medium and large-scale farmers should be equipped with insect mass-rearing techniques, as well as techniques of processing insect products and by-products.

\section{REFERENCES}

Akre, R.D., Hansen, L.D., and R.S. Zack (1991). Insect jewelry. American Entomologist, 37(2): 91-95.

Alexandratos, N. and J. Bruinsma (2012). World Agriculture towards 2030/2050. ESA Working Paper No. 12-03. FAO: Rome, Italy.

Beekeeping/Apiculture/Imkerei/Apicultura (2002). http://www.beekeeping.org/. Accessed 12 October, 2017.

Cerritos, R. (2011). Grasshoppers in agrosystems: Pest or food? CAB Reviews: Perspectives in Agriculture, Veterinary Science, Nutrition and Natural Resources, 6: 1-9.
Chae J., Kurokawa K., So, Y., Hwang, H.O., Kim, M., Park, J., Jo, Y., Lee, Y.S. and B.L. Lee (2012). Purification and characterization of tenecin 4 , a new antiGram-negative bacterial peptide, from the beetle Tenebrio molitor. Developmental \& Comparative Immunology, 36: 540-546.

Cherry, R. H. (1987). History of sericulture. Bull. Entomological Society of America, 33(2): 83-84.

Chidumayo, E.N. and K.J. Mbata (2002). Shifting cultivation, edible caterpillars and liveli-hoods in the Kopa Area of northern Zambia. Forests Trees and Liveli- hoods, 12: 175-193.

Costanza, R. (1997). The value of the world's ecosystem services and natural capital. Nature, 87:253-260.

Crane, E. (1983). The archaeology of beekeeping. Cornell University Press, Ithaca, NY. 360pp.

DeFoliart, G.R. (1992). Insects - An overlooked food resource. In: Adams, J. (ed.) Insect Potpourri: Adventures in Entomology. The Sandhill Crane Press, Inc., Gainesville, Florida. 336 pp. 44-48.

Durst, P. B. and K. Shono (2008). Edible forest insects: exploring new horizons and traditional practices. In: Durst, P.B., Johnson, D. V., Leslie, R. N. and Shono, K. (Eds.). Proceedings of a workshop on Asia-Pacific resources and their potential for development "Forest insects as food: humans bite back" 19-21 February 2008, Chiang Mai, Thailand Food and Agriculture Organization of The United Nations Regional Office for Asia and The Pacific Bangkok, Thailand. 241pp.

Elvin, M. C., Andrew, G. C., Huson, M., Maxwell, M. J., Pearson, R., Vuocolo, T., E Liyou, E. N., Wong, D., Merritt, D. and N. Dixon (2005). Synthesis and properties of crosslinked recombinant pro-resilin. Nature, 437: 999-1002.

Family of Nature Websites (2000). The Butterfly Website: Public butterfly gardens \& zoos. http://butterflywebsite.com/ gardens/index.cfm Last updated 14 June 2000. Accessed 14 November, 2002. 
FAO (2012). Assessing the Potential of Insects as Food and Feed in assuring Food Security. In: Vantomme, P., Mertens, E., van Huis, A. and Klunder, H. (Eds.). Summary Report of Technical Consultation Meeting. Rome, Italy, p. 145.

FAO (2013). Edible insects: future prospects for food and feed security. In: van Huis, A., Van Itterbeeck, J., Klunder, H., Mertens, E., Halloran, A., Muir, G. and Vantomme, P. (Eds.). FAO Forestry Paper No. 171. p. 201.

www.fao.org/forestry/edibleinsects

Fontaneto, D., Tommaseo-Ponzetta, M., Galli C., Risé, P., Glew, R. H. and M.G. Paoletti (2011). Differences in fatty acid composition between aquatic and terrestrial insects used as food in human nutrition. Ecology of Food and Nutrition, 50: 351-367.

Genetics Society of America. (1997). Fly Base: A database of the Drosophila genome. http://flybase.bio.indiana.edu/ Accessed 13 November, 2017.

Gerland, P., Raftery, A.E., Šev`cíková, H., Li, N., Gu, D., Spoorenberg, T., Alkema, L., Fosdick, B.K., Chunn, J., N. Lalic (2014). World population stabilization unlikely this century. Science, 346: 234-237.

Global Food Security (2015). Insects as Animal Feed: Roadmaps for UK research. Workshop held on Tuesday 4th August 2015, London, UK, p. 8. www.foodsecurity. ac.uk. Accessed 27th October, 2017.

Global Food Security (2015). Roadmaps for UK research In: Rivers, E. (Ed.). Workshop: Insects as Animal Feed. 4th August 2015, London, UK. 8p.

HMI (2012). Honey Marketing and International Trade ftp://ftp.fao.org/docrep/fao/012 /i0842e/i0842e16.pdf. Accessed 26th October, 2017.

Juma, C. (1993). Biodiversity prospecting: Using genetic resources for sustainable development. World Resources Institute, USA. $341 \mathrm{p}$.

Kampmeier G.E. and B.E. Irwin (2009). Commercialization of insects and their products. In: Resh, V. H. and Cardé, R. T.
(Eds.). Encyclopedia of Insects, 2nd Ed. Academic Press Inc: Burlington, MA, USA, pp. 220-227.

Kampmeier, G.E. and M.E. Irwin (2003). Commercialization of insects and their products. In: Resh, V. H. and Cardé, R. T. (Eds.). Encyclopedia of insects, Burlington, USA, Academic Press. pp. 252-260.

Krell, R. (1996). Value-added products from beekeeping. FAO Agric. Serv. Bull. 124 http://www.fao.org/docrep/w0076e/w0076e 00.htm Accessed 25 October, 2017.

Makkar, H.P.S., Tran, G., Heuzé, V. and P. Ankers (2014). State-of-the-art on use of insects as animal feed. Animal Feed Science and Technology, 197: 1-33.

Manning, G. (2000). A quick and simple introduction to Drosophila melanogaster. http://ceolas.org/fly/intro. Accessed 17 October, 2017.

Mariod, A.A. (2011). Insect oils: Nutritional and industrial applications. International News on Fats, Oils and Related Materials, 22: 266-268.

Munthali, S.M., and D.E.C. Mughogho (1992). Economic incentives for conservation: Beekeeping and Saturniidae caterpillar utilizetion by rural communities. Biodiversity and Conservation, 1: 143-154.

Murray, S.S., Schoeninger, M.J., Bunn, H.T., Pickering, T.R. and J.A. Marlett (2001). Nutritional composition of some wild plant foods and honey used by Hadza foragers of Tanzania. Journal of Food Composition and Analysis, 14: 3-13.

Nonaka, K. (2008). Edible forest insects: exploring new horizons and traditional practices. In: Durst, P. B., Johnson, D. V., Leslie, R. N. and Shono, K. (Eds). Proceedings of a workshop on AsiaPacific resources and their potential for development "Forest insects as food: humans bite back" 19-21 February 2008, Chiang Mai, Thailand Food and Agriculture Organization of The United Nations Regional Office for Asia and The Pacific Bangkok, Thailand. 241pp.

Offenberg, J. and D. Wiwatwitaya (2009). Weaver ants convert pest insects into food: 
prospects for the rural poor. Paper presented at the International Conference on Research, Food Security, Natural Resource Management and Rural Development, University of Hamburg, Germany, 68 October, 2009.

Premalatha M., Abbasi T. and S.A. Abbasi (2011). Energy-efficient food production to reduce global warming and ecodegradation: The use of edible insects. Renewable and Sustainable Energy Reviews, 15: 43574360.

Ramos-Elorduy, J. (2005). Insects: a hopeful food source. In: Paoletti, M. G. (Ed.). Ecological implications of mini livestock, Science Pub., Enfield NH, USA. pp. 263291.

Ravindran, V. and R. Blair (1993). Feed resources for poultry production in Asia and the Pacific: Animal protein sources. World's Poultry Science Journal, 49: 219235.

Schabel, H. G. (2008). Edible forest insects: exploring new horizons and traditional practices. In: Durst, P.B., Johnson, D.V., Leslie, R. N. and Shono, K. (Eds.). Proceedings of a workshop on Asia-Pacific resources and their potential for development "Forest insects as food: humans bite back" 19-21 February 2008, Chiang Mai, Thailand Food and Agriculture Organization of The United Nations Regional Office for Asia and The Pacific Bangkok, Thailand. 241p.
Tauber, M.J., Tauber, C.A., Daane, K.M., and K.S. Hagen (2000). Commercia-lization of predators: Recent lessons from green lacewings (Neuroptera: Chrysopidae: Chrysoperla). American Entomologist, 46(1): 26-38.

Tauber, M.J., Tauber, C.A., Daane, K.M., and K.S. Hagen (2000). Commerciali-zation of predators: Recent lessons from green lacewings (Neuroptera: Chrysopidae: Chrysoperla). American Entomologist., 46(1): 26-38

Umesh, R. N., Chandra Mohan, A. B., Ravibabu, G., Padiyar, P. A., Phillips, M. J., Mohan, C. V. and B. Vishnu Bhat (2009). Shrimp farmers in India: empowering small-scale farmers through a cluster-based approach. In: De Silva, S. S. and Davy, F. B. (Eds.). Success stories in Asian aquaculture. Springer, Netherlands. pp. 41-66.

Sumangala, R., Srikanth, S.K., Ashwini, V., Rekha, K.N. and K.B. Shenoy (2018). Spider diversity on Mangalore University Campus. Journal of Entomology and Zoology Studies, 6(2): 3186-3194.

Wegner, G.S. (2014). Spider Identification Guide. BASF Corporation. All rights reserved, pp. 1-60.

NJE Vol. 36: 71-80, 2020

Nigerian Journal of Entomology

Published by the Entomological Soc. of Nig.

www.esnjournal.com.ng

DOI.10.36108/NJE/0202/63.01.80 